\title{
PENGARUH SUPLEMENTASI FETAL CALF SERUM TERHADAP KEMAMPUAN MATURASI IN VITRO OOSIT SAPI
}

\section{EFFECT OF FETAL CALF SERUM SUPPLEMENTATION ON IN VITRO MATURATION ABILITY OF BOVINE OOCYTES}

\author{
Denvy Meidian Daoed*, Nono Ngadiyono, dan Diah Tri Widayati \\ Fakultas Peternakan, Universitas Gadjah Mada, Jl. Fauna No. 3, Bulaksumur, Yogyakarta, 55281
}

\section{INTISARI}

Penelitian ini memanfaatkan hasil samping rumah potong hewan (RPH) sebagai sumber oosit untuk in vitro fertilization (IVF). Untuk meningkatkan keberhasilan IVF dilakukan suplementasi fetal calf serum (FCS) pada medium maturasi in vitro. Ovarium sapi dari $\mathrm{RPH}$ dibawa ke laboratorium dalam medium $\mathrm{NaCl} 0,9 \%$ pada suhu $31-34^{\circ} \mathrm{C}$. Selanjutnya oosit diaspirasi menggunakan syringe $3 \mathrm{ml}$ dan jarum $23 \mathrm{G}$ yang berisi Dulbeco's-Phosphate Buffer Saline (DPBS), kemudian dimaturasikan pada inkubator $\mathrm{CO}_{2}$ modifikasi dalam medium Tissue Culture Medium-199 (TCM199) $\left(\mathrm{CO}_{2} 5 \%\right.$, kelembaban $99 \%$ dan suhu $\left.37-39^{\circ} \mathrm{C}\right)$. Oosit dibagi menjadi 2 kelompok yaitu kelompok kontrol (TCM199) dan kelompok perlakuan (TCM-199 + 10\% FCS). Angka maturasi dianalisa dengan Chi-Square, sedangkan kualitas oosit dianalisis secara deskriptif. Maturasi oosit sapi pada kelompok perlakuan berbeda nyata $(\mathrm{P} \leq 0,05)$ dibandingkan kelompok kontrol (55,22\% vs 40,09\%). Penggunaan $10 \%$ FCS pada medium maturasi dapat menghasilkan kualitas oosit matur yang lebih baik dibandingkan kelompok kontrol. Kesimpulan penelitian ini adalah penggunaan 10\% FCS suplementasi dapat meningkatkan kemampuan maturasi oosit sapi in vitro.

(Kata kunci: Fetal calf serum, Kultur oosit, Maturasi in vitro, Oosit sapi)

\section{ABSTRACT}

This study was conducted to investigate the utilization of ovaries from the slaughterhouse as oocytes source for in vitro fertilization (IVF). Fetal calf serum (FCS) was used as supplement of in-vitro maturation medium in order to increase the successfullness of IVF. Ovaries were collected from local slaughterhouse and transported to the laboratory using $0.9 \% \mathrm{NaCl}$ medium at $31-34^{\circ} \mathrm{C}$. The oocytes were aspirated by using a $3 \mathrm{ml}$ syringe and $23 \mathrm{G}$ needle containing Dulbeco's-Phosphate Buffer Saline (DPBS), then were maturated in modified $\mathrm{CO}_{2}$ incubator (99\% humidity and a temperature of 37-39 ${ }^{\circ}$ ) in Tissue Culture Medium-199 (TCM-199). Oocytes were divided into 2 groups: control group (TCM-199) and the treatment group (TCM-199 + 10\% FCS). Data was analyzed by Chi-Square anaiysis, and the quality of oocytes were analyzed descriptively. Maturation ability of bovine oocytes in the treatment group was significantly higher $(P \leq 0.05)$ than the control group $(55.22 \%$ vs $40.09 \%)$. In conclusion, the suplementation of $10 \%$ FCS in maturation medium improve the quality and ability of oocytes maturation.

(Key Words: Fetal calf serum, Oocytes culture, In vitro maturation, Bovine oocytes)

\section{Pendahuluan}

Perkembangan bioteknologi reproduksi ternak telah banyak menghasilkan manfaat bagi manusia khususnya dalam industri peternakan. Teknologi-teknologi tersebut antara lain adalah inseminasi buatan (IB) yang telah memasyarakat di daerah-daerah dan sudah membuahkan hasil (Rustanto dan Sugiono, 1997) dan transfer embrio (TE) yang saat ini masih dikembangkan dapat dilakukan untuk memperbanyak embrio. Untuk keperluan transfer embrio dibutuhkan embrio dalam jumlah yang banyak. Salah satu cara yang dapat dilakukan adalah dengan aplikasi teknologi in vitro

\footnotetext{
* Korespondensi (corresponding author):

Telp. +62 85328123592

E-mail: denvy_md@yahoo.com
}

fertilization (IVF) meliputi in vitro maturation (IVM) dan in vitro culture (IVC).

Ovarium sapi yang berasal dari rumah potong hewan (RPH) sesaat setelah penyembelihan dapat dimanfaatkan sebagai sumber oosit untuk keperluan in vitro maturasi sehingga dapat memudahkan in vitro fertilisasi (Pujol et al., 2004), namun keberhasilan IVF sampai ke tahap blastosist sangat tergantung pada beberapa faktor diantaranya jenis suplemen yang digunakan dalam media maturasi in vitro (Hammam et al., 2010), kualitas oosit yang digunakan (Lonergan et al., 2003; Anguita et al., 2007), serta resiko kontaminasi dan kondisi kultur (Sagirkaya et al., 2007). Jenis suplemen, kualitas oosit serta kondisi kultur yang baik sangat mendukung untuk meningkatkan kemampuan maturasi oosit in vitro.

Optimalisasi maturasi in vitro oosit antara lain adalah pengklasifikasian oosit, penambahan zat 
aditif berupa faktor pertumbuhan dan hormon (Shen et al., 2008), maupun berbagai macam serum. Klasifikasi oosit yang didasarkan pada kelengkapan struktur oosit sangat mempengaruhi maturasi in vitro dan perkembangan oosit sampai ke tahap blastosist (Alm et al., 2005; Ksiazkiewicz et al., 2007). Penggunaan serum seperti fetal calf serum (FCS) banyak digunakan dalam produksi embrio (Sagirkaya et al., 2004) karena mengandung epidermal growth factor (EGF) yang berperan sebagai regulator intraovarian dalam proses maturasi oosit (Mtango et al., 2003). Fetal calf serum telah dibuktikan bermanfaat selama kultur in vitro, namun kadar penggunaannya dan hasil yang diperoleh masih bervariasi (Abe et al., 2002; Holm et al., 2002; Rizos et al., 2002). Penelitian tentang pengaruh suplemen FCS terhadap kemampuan maturasi oosit sapi in vitro dilakukan dalam rangka untuk memanfaatkan hasil samping RPH dan sekaligus menambah referensi hasil IVF.

\section{Materi dan Metode}

\section{Waktu dan tempat penelitian}

Penelitian dilaksanakan pada bulan September sampai Desember 2012 di Laboratorium Fisiologi dan Reproduksi Ternak, Fakultas Peternakan, Universitas Gadjah Mada.

\section{Materi}

Bahan yang digunakan dalam penelitian ini adalah: ovarium sapi lokal hasil persilangan (sapi PO, sapi SimPO, dan sapi LimPO) sebagai sumber oosit yang diperoleh dari RPH Giwangan Yogyakarta, TCM- 199, D-PBS, BSA, heparin, Nacaffein, Na-piruvat, NaCL fisiologis, Pen-Strep, FCS, minyak mineral dan aquabides steril. Alat yang digunakan dalam penelitian ini adalah modifikasi Inkubator $\mathrm{CO}_{2}$, cawan petri disposibel berdiameter $35 \mathrm{~mm}$, syringe disposibel $3 \mathrm{ml}$, alatalat gelas: pipet ukur, pipet pasteur, tabung reaksi, Erlenmeyer, gelas beker dan alat-alat gelas lainnya, laminar air flow, mikroskop inverted, kamera Optilab, mikropipet, termos, penangas air, dan filter Millipore.

\section{Metode}

Koleksi ovaria. Ovaria diambil dari RPH setelah sapi disembelih, kemudian dicuci dengan larutan $\mathrm{NaCl}$ 0,9\% yang telah diberi penisilin $\mathrm{G}$ dan streptomisin sulfate, ditempatkan dalam termos yang berisi larutan $(100 \mathrm{ml} \mathrm{NaCl} 0,9 \%+100 \mathrm{IU} / \mathrm{ml}$ penisilin $\mathrm{G}+10 \mathrm{mg} / \mathrm{ml}$ streptomisin sulfat) pada suhu $31-34^{\circ} \mathrm{C}$. Ovaria dibawa ke laboratorium dalam waktu tidak lebih dari 3 jam.

Aspirasi dan pencarian oosit. Oosit diaspirasi menggunakan syringe $3 \mathrm{ml}$ dan jarum 23
$\mathrm{G}$ yang berisi D-PBS $+3 \%$ FCS. Cairan yang diperoleh dari folikel ditampung dalam tabung yang terpisah, kemudian dilakukan pencarian oosit. Pencarian dan evaluasi oosit dilakukan dengan menuangkan cairan folikel pada cawan petri di bawah mikroskop stereo dengan pembesaran 10x.

Klasifikasi oosit. Oosit diklasifikasikan berdasarkan kelengkapan strukturnya dan diseleksi mengikuti Gordon (1994): kelas 1) lapisan sel kumulus utuh dan kompak, ooplasma rata dan tidak bergranula, kelas 2) lapisan kumulus tidak utuh (minimal setengah keliling oosit) dan ooplasma rata, kelas 3) oosit gundul tanpa lapisan kumulus, kelas 4) oosit dikelilingi oleh fibrin yang menyerupai sarang laba-laba. Oosit yang digunakan dalam penelitian ini hanya oosit kelas 1 dan 2 .

Maturasi oosit. Oosit yang diperoleh dipisahkan ke dalam 2 (dua) kelompok yaitu kelompok kontrol dan kelompok perlakuan. Kelompok kontrol diletakkan dalam media maturasi $100 \mathrm{ml} \mathrm{TCM}-199$ (25 mM Hepes TCM-199 dengan garam Earle's) yang telah diberi antibiotik (Penisilin G $100 \mathrm{IU} / \mathrm{ml}$ dan streptomisin sulfat 10 $\mathrm{mg} / \mathrm{ml}$ ) tanpa FCS, sedang pada kelompok perlakuan oosit diletakkan dalam media maturasi yang sama dan diberi tambahan $10 \%$ FCS dari 100 ml TCM-199. Proses inkubasi dilakukan dengan menggunakan modifikasi inkubator $\mathrm{CO}_{2}$. Oosit yang diletakkan pada media maturasi ditutup dengan minyak mineral kemudian petridishnya dimasukkan dalam kantong aluminium kedap udara, lalu melalui filter millipore $22 \mathrm{\eta m}$ gas $\mathrm{CO}_{2}$ dari saluran pernapasan ditiupkan dalam aluminium tersebut hingga plastiknya mengembung, segera ditutup dan dimasukkan dalam aluminium foil sehingga tidak tembus cahaya. Proses inkubasi dilakukan dengan memasukkan dalam inkubator pada suhu $39^{\circ} \mathrm{C}$ dan kelembaban $99 \%$ selama 22 jam.

Pengamatan. Oosit yang sudah dimaturasi in vitro selama 22 jam kemudian diamati dengan mikroskop stereo. Terjadinya maturasi ditandai dengan pemekaran sel-sel kumulus, zona pelusida terlihat semakin jelas, dan munculnya polar bodi pertama.

\section{Analisis data}

Variabel yang diamati meliputi persentase oosit yang matur dan kualitas oosit yang dapat dilihat dari pemekaran sel-sel kumulus dan terlihat jelasnya zona pelusida. Angka maturasi adalah jumlah oosit yang matur dibagi jumlah total oosit yang diinseminasi dikalikan seratus, sedangkan kualitas oosit adalah bentuk oosit yang proporsional yang diamati berdasarkan grade-nya. Data persentase oosit yang matur dianalisis secara 
statistik menggunakan Chi-Square dan kualitas oosit dianalisis secara deskriptif.

\section{Hasil dan Pembahasan}

Maturasi oosit dapat diamati dengan dua cara yaitu maturasi sitoplasma yang ditandai oleh semakin transparannya zona pelusida oosit serta maturasi secara keseluruhan yang ditandai dengan ekspansi sel-sel kumulus yang mengelilingi oosit. Hasil penelitian di laboratorium menunjukkan bahwa dalam kelompok perlakuan yang diberi penambahan FCS sebanyak 10\% memperlihatkan jumlah oosit matur yang lebih besar dibandingkan dengan kelompok kontrol yang tidak diberi FCS.

Hasil penelitian menunjukkan bahwa penambahan FCS pada medium maturasi in vitro memperlihatkan pengaruh yang signifikan antara dua kelompok perlakuan. Hasil penelitian ini sama dengan hasil penelitian Sagirkaya et al. (2004) yang menunjukkan efektivitas penggunaan 10\% FCS jika dibandingkan dengan serum lain dan atau tanpa serum. Hal ini disebabkan karena FCS merupakan serum fetus sapi yang banyak mengandung zat yang dibutuhkan oleh oosit selama proses kultur in vitro. Mucci et al. (2006) menyatakan bahwa FCS dapat menyediakan substrat energi, asam amino, vitamin, growth factor dan antioksidan. Zat-zat tersebut merupakan zat yang bermanfaat selama proses kultur in vitro. Fetal calf serum juga dapat bersifat sebagai biosecurity yang dapat menghambat resiko kontaminasi patogen selama kondisi kultur in vitro (Moore dan Bonilla, 2006).

Hasil analisis menunjukkan perbedaan yang nyata $(\mathrm{P} \leq 0,05)$ antara kelompok perlakuan dan kelompok kontrol. Persentase oosit matur pada kelompok perlakuan sebesar 55,22\% lebih besar dibandingkan kelompok kontrol sebesar 40,09\% (Tabel 1). Hasil ini hampir sama dengan yang diperoleh Rutledge et al. (1986) yang mendapatkan tingginya angka maturasi oosit pada penambahan $10 \%$ FCS dibandingkan dengan $20 \%, 5 \%$, dan $1 \%$ secara berturut-turut.

Ciri yang paling menonjol dari oosit matur adalah ekspansi sel-sel kumulus serta semakin ter- lihat jelas zona pelusida oosit. Secara in vitro ekspansi atau pemekaran sel-sel kumulus sangat dipengaruhi oleh berbagai faktor diantaranya medium dan kondisi kultur selama proses inkubasi (Wattimena, 2006), dan aktivitas berbagai komponen yang melibatkan enzim, dan hormon (Widayati, 1998), serta komposisi medium kultur yang digunakan (Tavares et al., 2008).

Proses pengklasifikasian oosit juga sangat diperlukan sebelum maturasi in vitro, karena grade oosit ditentukan oleh kelengkapan struktur dari oosit tersebut. Grade oosit juga dapat mempengaruhi kualitas maturasi. Oosit dengan selsel kumulus yang intak (grade 1) dan dimaturasi dengan penambahan FCS akan menyebabkan kualitas maturasi yang lebih baik dibanding dengan oosit yang hanya memiliki sebagian sel-sel kumulus (grade 2) atau tanpa penambahan FCS pada medium maturasinya. Hal ini berkaitan dengan fungsi FCS yang dapat menyediakan protein bagi oosit selama proses maturasi. Gambar 1 menyajikan oosit grade 1 yang digunakan dalam penelitian.

Dari Gambar 1 dapat dilihat perbedaan antara oosit yang dimaturasi dalam kelompok kontrol dan perlakuan. Oosit pada kelompok perlakuan mempunyai kualitas oosit matur lebih baik yang ditandai dengan struktur sel-sel kumulus dan nukleus yang lebih proporsional dibandingkan dengan oosit matur pada kelompok kontrol. Hal ini disebabkan oleh komponen FCS yang tidak terdapat pada kelompok kontrol. Hasil yang sama juga dilaporkan oleh Lorenzo et al. (1994) bahwa besarnya pengaruh FCS yang ditambahkan dalam medium maturasi in vitro pada kelompok oosit yang memiliki COCs, berkaitan dengan peran FCS yang sangat dibutuhkan oleh FSH yang membuat terjadinya ekspansi sel-sel kumulus, memperbaiki viabilitas sel, dan menyelesaikan pembelahan meiosis pertama.

Cumulus oocyte complexes (COCs) yang dimaturasi in vitro dalam medium maturasi yang disuplementasi fetal calf serum akan mengalami kemampuan perkembangan maturasi yang lebih baik dibandingkan dengan oosit yang memiliki selsel kumulus sebagian. Hal ini disebabkan selain

Tabel 1. Persentase oosit yang matur dari dua perlakuan setelah maturasi in vitro (percentage of maturation oocytes in the two treatment groups after in vitro maturation)

\begin{tabular}{lcc}
\hline \hline \multicolumn{1}{c}{ Kelompok (group) } & $\begin{array}{c}\text { Jumlah oosit yang diamati } \\
\text { (total oocytes observated) }\end{array}$ & $\begin{array}{c}\text { Jumlah oosit yang matur } \\
\text { (total oocytes mature) }\end{array}$ \\
\hline $\begin{array}{l}\text { Perlakuan (+FCS 10\%) (experiment (with FCS } \\
10 \%) \text { ) }\end{array}$ & 230 & $127(55,22 \%)^{\mathrm{b}}$ \\
Kontrol (tanpa FCS) (control (within FCS)) & 222 & $89(40,09 \%)^{\mathrm{a}}$ \\
\hline
\end{tabular}

${ }^{\mathrm{a}, \mathrm{b}}$ Superskrip yang berbeda pada kolom yang sama menunjukkan perbedaan yang nyata (different superscripts at the same column indicate significant differences). 


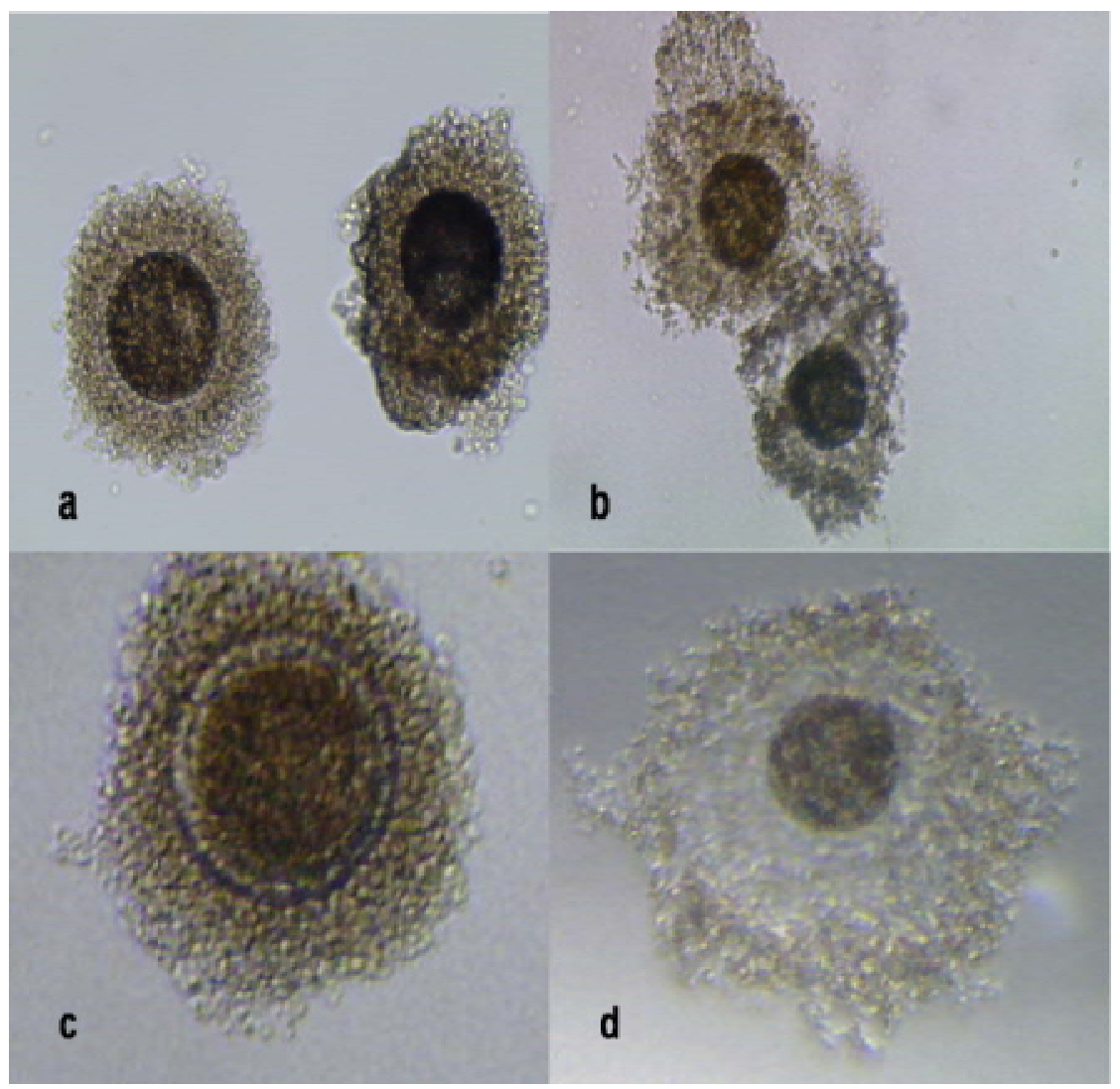

Gambar 1. Oosit grade 1 kelompok perlakuan (+FCS), (a) sebelum maturasi dan (b) setelah maturasi; serta oosit kelompok kontrol (tanpa FCS) (c) sebelum maturasi dan (d) setelah maturasi (oocyte grade 1 experiment group ( $+F C S)$, (a) before maturation and (b) after maturation; oocyte control experiment (absence FCS) (c) before maturation and (d) after maturation).

fungsi FCS yang menginaktifkan radikal bebas dan logam berat selama kondisi kultur (Sagirkaya et al., 2004), sel-sel kumulus juga berperan dalam mekanisme kompleks yang melibatkan komunikasi intraseluler oosit dan sel-sel somatis selama proses maturasi (Zhu et al., 2007).

Kualitas oosit merupakan faktor yang sangat penting dalam menentukan maturasi oosit. Sama halnya dengan FCS yang dapat meningkatkan angka maturasi dibanding serum lainnya seperti bovine serum albumin (BSA) (Koo et al., 1997) dan synthetic serum subtitute (SSS) (Sagirkaya et al., 2004). Oosit dengan sel-sel kumulus intak menyediakan faktor esensial selama proses maturasi, menjaga oosit dan berperan selama tahapan pembelahan meiosis serta mendukung maturasi sitoplasma. Pada babi oosit sel-sel kumulus intak dapat menurunkan penetrasi spermatozoa pada saat fertilisasi in vitro (Wongsrikeao et al., 2005), sedangkan pada manusia oosit matur dengan sel-sel kumulus intak sangat berpotensi untuk terfertilisasi saat inseminasi namun rendah fertilitasnya.

Kualitas oosit yang tidak bagus seperti kurangnya sel-sel kumulus yang mengelilingi oosit akan menyebabkan penurunan metabolisme antara oosit dan sel-sel kumulus yang mengakibatkan tidak tersedianya nutrisi yang sangat dibutuhkan selama proses maturasi (Widayati, 1998). Selain itu oosit yang memiliki sel-sel kumulus intak atau COCs akan memungkinkan terjadinya komunikasi intraseluler melalui gap junction yang merupakan tempat transfer sebagian oosit denud, meningkatkan in vitro maturasi dan menyelamatkan oosit dari degradasi (Adiva, 2010).

Oosit sel-sel kumulus sebagian (grade 2) akan menyebabkan maturasi yang kurang sempurna. Hal ini berkaitan dengan maturasi sitoplasma atau transformasi inti yang ditandai dengan diferensiasi dan pembentukan polar bodi I serta maturasi membran (germinal vesicle) yang ditandai oleh pemekaran sel-sel kumulus dan terputusnya membran (germinal vesicle break down). Berikut adalah gambar yang menyajikan oosit grade 2 yang digunakan dalam penelitian.

Hasil analisis deskriptif maturasi oosit in vitro menggunakan oosit grade 2 memperlihatkan bahwa antara kelompok perlakuan mempunyai kualitas yang baik (seperti yang terlihat pada Gambar 2) dibandingkan dengan oosit yang dimaturasikan dalam kelompok kontrol. Gambar 2 


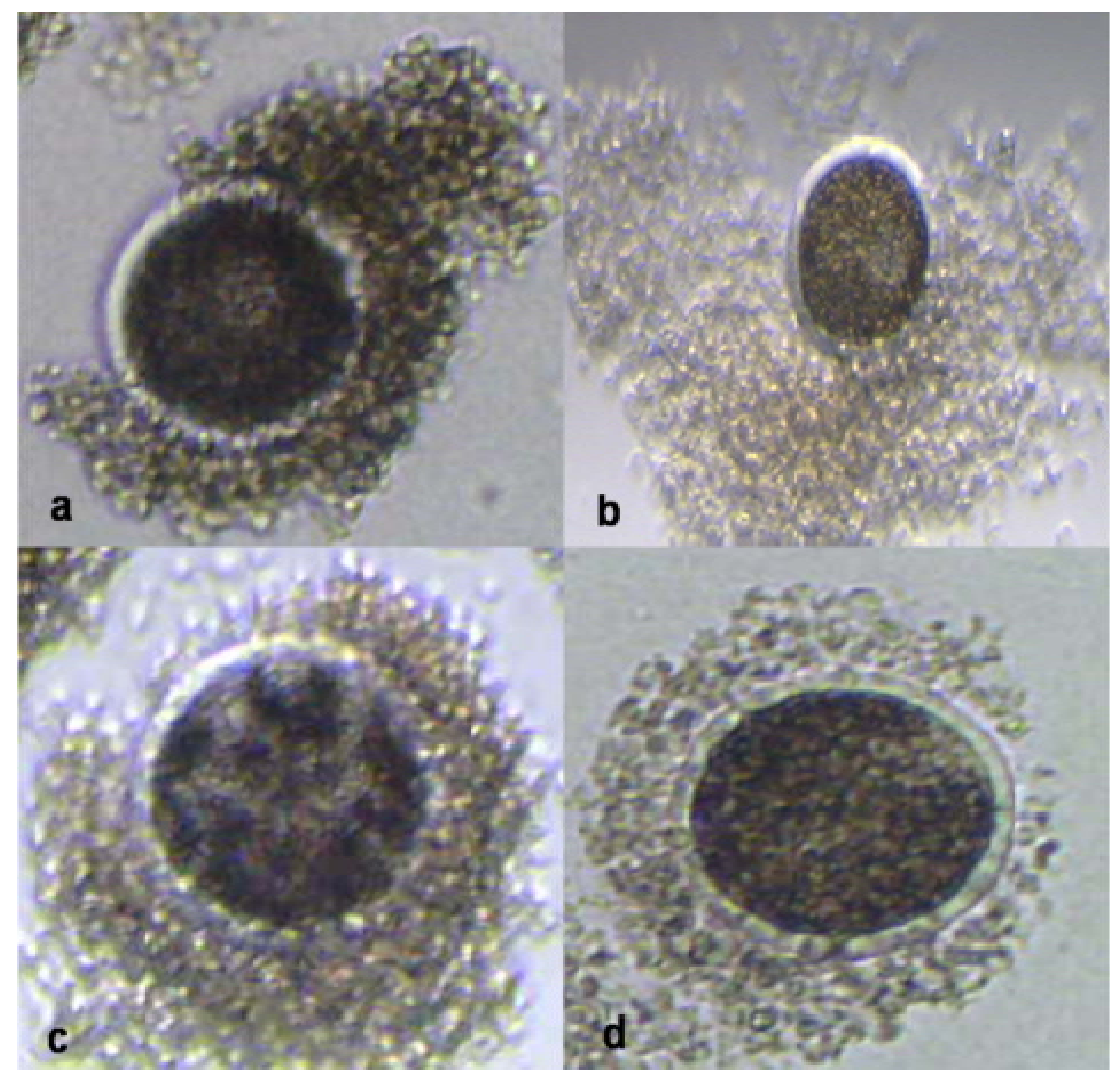

Gambar 2. Oosit grade 2 kelompok perlakuan (+FCS), (a) sebelum maturasi dan (b) setelah maturasi; serta oosit kelompok kontrol (tanpa FCS) (c) sebelum maturasi dan (d) setelah maturasi (oocyte grade 2 experiment group ( $+F C S$ ), (a) before maturation and (b) after maturation; oocyte control group (absence FCS) (c) before maturation and (d) after maturation).

memperlihatkan struktur oosit yang terlihat jelas khususnya pada bagian zona pelusida. Semakin transparannya zona pelusida merupakan indikasi dari maturasi oosit yang sempurna. Hasil penelitian yang sama diperoleh Widayati (1998), yang menemukan tidak efisiennya penambahan sel-sel kumulus pada media maturasi terhadap angka maturasi oosit, namun meningkatkan angka fertilisasi dan pembelahan embrio. Leivas et al. (2011) melaporkan bahwa tingginya angka maturasi pada oosit yang diberi perlakuan FCS yang disebabkan oleh kandungan FCS yang merupakan sumber protein dan sangat mendukung aktivitas biologik oosit selama proses maturasi in vitro.

Oosit sel-sel kumulus intak (COCs) serta oosit sel-sel kumulus sebagian mempunyai mekanisme yang sama dalam berkomunikasi dengan sel-sel kumulus untuk mematangkan oosit, namun oosit sel-sel kumulus intak mempunyai potensi yang lebih besar dibanding oosit sel-sel kumulus sebagian. Hal ini disebabkan karena sistem calpain-calpastatin yang ditemukan dalam pola ekspresi gen pada COCs dan tidak ditemukan pada naked oocytes (oosit sel-sel kumulus sebagian) (Zhu et al., 2007). Sistem calpain-calpastatin merupakan jalur signal selular yang memediasi kalsium, pengangkutan enzim, aktivasi reseptor serta proses seluler lainnya yang meliputi siklus regulasi sel, diferensiasi sel serta apoptosis (Ben-Aharon et al., 2005). Sistem calpain-calpastatin inilah yang membedakan kualitas maturasi antara oosit sel-sel kumulus intak dan oosit sel-sel kumulus sebagian, baik dalam pemekaran sel-sel kumulus maupun transparannya zona pelusida.

Keadaan oosit sel-sel kumulus sebagian juga sangat mempengaruhi maturasi sitoplasma, hal ini diakibatkan karena selama proses IVM sel-sel kumulus sangat berperan sebagai penghubung dan menyediakan gup junction yang merupakan jalur lintas nutrisi bagi oosit (Widayati, 1998). Pada proses IVF, oosit sel-sel kumulus sebagian akan mengalami keterlambatan fertilisasi, hal ini disebabkan karena sel-sel kumulus yang mengelilingi oosit akan menciptakan suatu lingkungan mikro yang sangat spesifik untuk proses fertilisasi in vitro (Yokoo dan Sato, 2004). Oosit sel-sel kumulus intak akan menciptakan lingkungan mikro dalam medium kultur yang lebih baik untuk aktifitas oosit selama proses maturasi dibandingkan oosit sel-sel kumulus sebagian. 


\section{Kesimpulan dan Saran}

\section{Kesimpulan}

Suplementasi fetal calf serum (FCS) dalam media maturasi dapat meningkatkan angka maturasi dan dapat memperbaiki kualitas maturasi in vitro oosit sapi berdasarkan grade-nya.

\section{Saran}

Proses maturasi oosit secara in vitro dengan menggunakan FCS $10 \%$ dan inkubator $\mathrm{CO}_{2}$ modifikasi dapat menghasilkan oosit dengan maturasi yang sempurna, sehingga diharapkan penelitian lanjutan seperti fertilisasi in vitro dan kultur embrio in vitro dengan kadar FCS $10 \%$ dan menggunakan inkubator $\mathrm{CO}_{2}$ modifikasi.

\section{Daftar Pustaka}

Abe, H., S. Yamashita, T. Itoh, T. Satoh and H. Hoshi. 2002. Ultrastructure of bovine embryos developed from in vitro-matured and fertilized oocytes: comparative morphological evaluation of embryos cultured either in serum-free medium or in serum-suplemented medium. Mol. Repr. Dev. 56: 326-336.

Adiva, N. S., P. Astuti, dan D.T. Widyawati. 2010. Pengaruh penambahan chorionic gonadotrophin pada medium maturasi terhadap kemampuan maturasi, fertilisasi, dan perkembangan embrio secara in vitro kambing Peranakan Ettawa. Buletin Peternakan 34: 8-15.

Alm, H., H. Torner, B. Lohrke, T. Viergutz, I. M. Ghoneim and W. Kanitz. 2005. Bovine blastocyst development rate in vitro is influence by selection of oocytes by brilliant cresyl blue staining before IVM as indicator for glucose-6-phosphate dehydrogenase activity. Theriogenology 63: 194-205.

Anguita, B., L. Vandaele, B. Mateusen, D. Maes and A. Van Soom. 2007. Developmental competence of bovine oocytes is not related to apoptosis incidence in oocytes, cumulus cells and blastocysts. Theriogenology 67: 3749.

Ben-Aharon, I., D. Ben-Yosef, B. Amit and R. Shalgi. 2005. Expression and immunolocalization of the calpain-calpastatin system in the human oocyte. Fertil. Steril. 83: 1807-1813.

Gordon, I. 1994. Laboratory Production of Cattle Embrio. Cambridge University Press. United Kingdom.
Hammam, A. M., C. S. Whisnant, A. Elias, S. M. Zaabel, A. O. Hegab and E. M. Abu-El Naga. 2010. Effect of media, sera and hormones on in vitro maturation and fertilization of water buffallos (bubalus bubalis). J. Anim. Vet. Adv. 9: 27-31.

Holm, P., P.J. Booth, M.H. Schimidit, T. Greve and H. Callesen. 2002. High Bovine. Blastocysts development in a statistic in vitro production system using SOFaa medium suplemented with sodium citrate and myo-inositol with or without serum proteins. Theriogenology 52: 683-700.

Koo, D. B., N. H. Kim, H. T. Lee and K. S. Chung. 1997. Effects of fetal calf serum, amino acids, vitamins and insulin and blastocoel formation on hatching of in vivo and IVM/IVF-derived porcine embrio developing in vitro. Theriogenology 48: 791-802.

Ksiazkiewicz, K. L., J. Opiela and B. Rynska. 2007. Effects of oocyte quality, semen donor and embryo co-culture system on the efficiency of blastocyst production in goats. Theriogenology 68: 736-744.

Leivas, F. G., D. S. Brum, S. S. Fialho, W. P. Saliba, M. T. T. Alvim, M. L. Bernardi, M. I. B. Rubin and C. A. M. Silva. 2011. Fetal calf serum enhances in vitro production of Bos taurus indicus embryos. Theriogenology 75 : 429-433.

Lonergan, P., D. Rizos, A. G. Adan, T. Fair and M. T. Boland. 2003. Oocyte and embryo quality: affect of origin, culture conditions and gene expression patterns. Reprod. Domest. Anim. 38: 59-67.

Lorenzo, P. L., M. J. Illera, J. C. Illera and M. Illera. 1994. Role of EGF, IGF-I, sera and cumulus cells on maturation in vitro of bovine oocytes. Theriogenology 44: 109-118.

Moore, K. and A. Q. Bonilla. 2006. Cryopreservation of mammalian embryo. Biomed. Sci. 8: 19-32.

Mtango, N. R., M. D. Varisanga, Y. J. Dong, R. Rajamahendran and T. Suzuki. 2003. Growth factors and growth hormone enhance in vitro embryo production and post-thaw servival of vitrified bovine blastocyst. Theriogenology 59: 1393-1402.

Mucci, N. J. A., G. G. Kaiser, F. Hozbor, J. Cabodevila and R. H. Alberio. 2006. Effect of estrous cow serum during bovine embryo culture on blastocyst development and cryotolerance after slow freezing or vitrification. Theriogenelogy 65: 15-26. 
Pujol, M., M. L. Bejar and M. T. Paramio. 2004. Developmental competence of heifer oocytes selected using the brilliant cresyl blue (BCB) test. Theriogenology 61: 35-44.

Rizos, D., S. Papadopoulo, P. Duffy, M. Wade, K. Quinn, M. P. Boland and P. Lonergan. 2002. Embryo survival and recipient pregnancy rates after transfer of fresh or vitrified, in vivo or in vitro produced ovine blastocysts. J. Anim. Sci. 106: 395-406.

Rustanto dan Sugiono. 1997. Lahirnya pedet tabung pertama di Indonesia. Infovet. Edisi 5, September. Pp. 24-25.

Rutledge, M. L., H. M. Florman and N. L. First. 1986. The molecular biology of mammalian oocyte maturation. J. Biol. Fert. 74: 35-44.

Sagirkaya, H., M. Misirlioglu, A. Kaya, N. L. First, J. J. Parrish and E. Memili. 2007. Developmental potential of bovine oocytes cultured in different maturation and culture conditions. Anim. Reprod. Sci. 101: 225-240.

Sagirkaya, H., M. Yaúmur, Z. Nur and M. K. Soylu. 2004. Replacement of fetal calf serum with synthetic serum substitute in the in vitro maturation medium: effects on maturation, fertilization and subsequent development of cattle oocytes in vitro. Vet. Anim. Sci. 28: 779-784.

Shen, P. C., S. N. Lee, B. T. Liu, F. H. Chub, C. H. Wang, H. H. Lin and W. T. K. Chengc. 2008. The effect of activation treatments on the development of reconstructed bovine oocytes. Anim. Reprod. Sci. 106: 1-12.
Tavares, L. M. T., W. B. Feitosa, M. R. B. Mello, A. C. Nicácio, A. S. Lima, M. E. O. A. Assumpcao and J. A. Visintin. 2008. Is the early reduction of fetal calf serum concentration in bovine in vitro embryo culture beneficial. J. Anim. Reprod. 5: 34-38.

Wattimena, J., T. R. Tagama, dan B. Hadisusanto. 2006. Pengaruh jenis dan konsentrasi serum terhadap tingkat maturasi oosit domba in vitro. Anim. Reprod. Sci. 8: 94-99.

Widayati, D. T. 1998. Pengaruh penambahan sel-sel kumulus pada media maturasi terhadap kemampuan maturasi oosit, fertilisasi dan perkembangan embrio sapi Peranakan Ongol in vitro. Tesis Program Sains Veterinary. Pascasarjana Universitas Gadjah Mada. Yogyakarta.

Wongsrikeao, P., Y. Kaneshige, R. Ooki, M. Taniguchi, B. Nii. M. Agung and T. Otoi. 2005. Effect of the removal of cumulus cells on the nuclear maturation, fertilization and development of porcine oocytes. Reprod. Domest. Anim. 40: 166-170.

Yokoo, M. and E. Sato. 2004. Cumulus-oocyte complex interactions during oocytes maturation. Int. Rev. Cytol. 235: 251-291.

Zhu, G. Y., S. T. Feng, J. T. Li, Y. L. Mu, D. K. Pan and B. R. Guo. 2007. Comparison of gene expression pattern between porcine cumulus oocytes complexes and naked oocytes. J. Anim. Sci. 37: 57-63. 